[Radiocarbon, Vol. 10, No. 2, 1968, P. 346-349]

\title{
OAK RIDGE ASSOCIATED UNIVERSITIES RADIOCARBON DATES II
}

\author{
JOHN E. NOAKES, S. M. KIM, and F. FISCHER*
}

\author{
Special Training Division, Oak Ridge Associated Universities, \\ Oak Ridge, Tennessee
}

The Radiocarbon Dating Laboratories of the Oak Ridge Associated Universities (ORAU) has previously published radiocarbon dates under the Oak Ridge Institute of Nuclear Studies (ORINS) name. ORINS has recently changed its name to ORAU and its laboratories and programs have accordingly assumed this new name. The ORINS prefix, which previously designated the published radiocarbon dates of this laboratory, will be continued to minimize confusion in the literature.

The radiocarbon dating program carried out at this laboratory is primarily concerned with assisting the ORAU Special Training Program in its teaching and research activities. Radiocarbon dates which appear in this paper represent samples submitted from research groups associated with the 41 universities which make up ORAU and by other college and university personnel who do not have access to radiocarbon dating facilities.

Carbon samples are chemically synthesized to liquid benzene and their $\mathrm{C}^{14}$ activity determined by liquid scintillation spectroscopy. Samples are first converted to lithium carbide and then to acetylene gas as described by Barker (1953). The acetylene is catalytically trimerized to benzene by a method described by Noakes et al. (1965). Chemical yields for the synthesized benzene routinely approach $90 \%$ with no evidence of chemical impurities or carbon isotope fractionation occurring in the chemistry.

A Packard Tricarb Model 314 D.C. liquid scintillation spectrometer, which has been modified for low level counting, is used to count the benzene samples. Counting efficiency is $50 \%$ when operating at a voltage of 800 with discriminator setting of 100-800-1000. Background count rate is $1.7 \mathrm{c} / \mathrm{m}$ with a $5 \mathrm{cc}$ benzene sample. Shielding consists of $4 \mathrm{in}$. of lead with coincidence and anticoincidence systems.

The modern reference standard is $0.95 \%$ activity of NBS oxalic acid standard which is $6.82 \mathrm{c} / \mathrm{m} / \mathrm{g}$ carbon. Ages are calculated on a $\mathrm{C}^{14}$ half-life of $5570 \mathrm{yr}$ as suggested by Godwin (1962). The statistics quoted are compiled as one standard deviation $\left(l_{\sigma}\right)$ of the uncertainty involved in counting background, standard, and sample.

\section{ACKNOWLEDGMENTS}

Dr. Brian Logan, Geol. Dept., Univ. of W. Australia, contributed many samples and helped in the evaluation. Dr. James Harding of Oceanonics, Inc. and William Bryant, Oceanog. Dept., Texas A \& M Univ., submitted many marine samples and assisted in their evaluation. Mr. Darwin Chapman, a research assistant at the ORAU Special Training Division, assisted in sample preparation and counting.

* ORAU Research Participant, Graduate Student, UCLA at San Diego, California. 
Financial support was received from the Division of Biology and Medicine and the Division of Nuclear Education and Training through the ORAU contract with the Atomic Energy Commission, No. AT(40-1)GEN-33.

\section{SAMPLE DESCRIPTIONS \\ I. GEOLOGIC SAMPLES \\ A. Campeche Bank, Yucatan}

Series of cores were taken from Campeche Bank, Yucatan, for study of physical, chemical, and geochemical properties of carbonate sediments in the area. Cores were coll. on various cruises of Texas A \& M research vessel, "R. V. Alaminos," during 1965 and 1966.

$\mathrm{CaCO}_{3}$ material from middle and lower sections of core (21E-65-A4) from Campeche Bank (20 $-20^{\prime}$ N Lat, $92^{\circ} 1712^{\prime}$ W Long); water depth 90 fms. Coll. 1965 by William Bryant, Dept. of Geol. Oceanog., Texas A \& M Univ.; subm. 1965. Comment: medium-grained dark-gray calcarenite with lithic fragments in $300 \mathrm{~cm}$ section graded to light-gray calcilutite with dark-gray calcarenite with blebs of dark clay at $1000 \mathrm{~cm}$ section.

Lab No. Core Interval $(\mathrm{cm}) \quad \mathrm{C}^{14}$ Date

\begin{tabular}{|c|c|c|}
\hline ORINS-65 & $610-620$ & $\begin{array}{l}\mathbf{8 , 9 3 6} \pm \mathbf{9 0} \\
\mathbf{6 , 9 8 6} \text { в.c. }\end{array}$ \\
\hline ORINS-66 & $670-680$ & $\begin{array}{l}9,180 \pm 90 \\
7,230 \text { в.с. }\end{array}$ \\
\hline ORINS-68 & $780-790$ & $\begin{array}{l}9,323 \pm 100 \\
7,373 \text { в.с. }\end{array}$ \\
\hline ORINS-69 & $920-930$ & $\begin{array}{c}10,267 \pm 105 \\
8,317 \text { в.с. }\end{array}$ \\
\hline ORINS-72 & 950.960 & $\begin{array}{c}11,078 \pm 130 \\
9,128 \text { в.с. }\end{array}$ \\
\hline ORINS-70 & $960-970$ & $\begin{array}{l}12,585 \pm 100 \\
10,635 \text { в.с. }\end{array}$ \\
\hline ORINS-73 & $1000-1010$ & $\begin{array}{l}14,750 \pm 130 \\
12,800 \text { в.с. }\end{array}$ \\
\hline ORINS-63. & Campeche Bank, Sample 8E-65-A4 & $\begin{array}{l}15,000 \pm 15 \\
13,050 \text { в.с. }\end{array}$ \\
\hline
\end{tabular}

Whitish-gray fine-grained calcilutite from upper middle section (interval 380 to $390 \mathrm{~cm}$ ) of core from Campeche Bank $\left(21^{\circ}-59^{\prime} \mathrm{N}\right.$ Lat, 92-19' W Long); water depth 70 fms. Coll. 1965 by William Bryant; subm. 1965. Comment: $\mathrm{CaCO}_{3}$ content less than $80 \%$ with pellets and dark-gray lithic fragments. 
ORINS-71. Campeche Bank, Sample 10E-65-A4

Medium- to coarse-grained gray calcarenite from bottom (1210 to $1220 \mathrm{~cm}$ ) of core from Campeche Bank (20 $59^{\prime} \mathrm{N}$ Lat, $96^{\circ} 26^{\prime} \mathrm{W}$ Long); water depth 73 fms. Coll. 1965 by William Bryant; subm. 1965. Comment: $\mathrm{CaCO}_{3}$ content less than $80 \%$ with admixture of brown silt and clay. $\mathrm{C}^{14}$ date chronology of this core from 100 to $1150 \mathrm{~cm}$ intervals, publ. by Noakes (1967).

\section{B. Shark Bay, Western Australia}

Shark Bay is lagoonal sea lying between $\left(26^{\circ} 45^{\prime} \mathrm{S}\right.$ Lat, $24^{\circ} 30^{\prime} \mathrm{S}$ Long) on W coast of Australia. Since 1964, a marine research group from the Dept. of Geol., Univ. of W. Australia, has been conducting research programs on carbonate sedimentation and diagenesis of carbonate sediments in Shark Bay. The following $\mathrm{C}^{14}$ dates are mainly on shell material obtained from emergent Quaternary sediments in the area.

ORINS-62. Shark Bay, B265133

$$
424 \pm 86
$$

\section{A.D. 1,526}

Oöid sand from Sta. B265133, Hamelin Pool W. Australia $\left(26^{\circ}\right.$ $08^{\prime} \mathrm{S}$ Lat, $113^{\circ} 57^{\prime} \mathrm{E}$ Long). Oöids are quartz nucleated and found in 4 to $5 \mathrm{ft}$ depth of Anchorage Bank. Coll. 1965; subm. by Brian W. Logan.

\section{ORINS-80. Shark Bay, L $157001 \quad 27,861 \pm 630$ 25,911 B.c.}

Coral (Lobophillia corymbosa) (Forskal) from emergent coral reef, Tetradon Loop, Dirk Hartog I., Shark Bay, W. Australia, (25 $27^{\prime}$ S Lat, $113^{\circ} 07^{\prime} \mathrm{E}$ Long). Reef top is ca. $10 \mathrm{ft}$ above present mean sea-level. Coll. 1957; subm. by Brian W. Logan.

ORINS-79. Shark Bay, L 157002

$>\mathbf{3 0 , 0 0 0}$

Coral (Galaxea fascicularis) (Linne) from same location and emergent coral reef as L 157001. Coll. 1957; subm. by Brian W. Logan.

ORINS-61. Shark Bay, G 266001

$30,532 \pm 1078$

28,582 в.c.

Marine pelecypods (Hemicardium hemicardium, Circe sugillata, Chama sp., Fargum unedo, Circe plicatina, Pitarina citrine) from subsurface intertidal zone, Gladstone embayment, Shark Bay, W. Australia (25 $59^{\prime} \mathrm{S}$ Lat, $114^{\circ} 15^{\prime} \mathrm{E}$ Long). Sample from 2 cores, over 6-in. interval ca. $4 \mathrm{ft}$ below mean high water level. Coll. 1966; subm. by G. R. Graves.

\section{ORINS-78. Shark Bay, 6266002}

$36,888 \pm 2750$

34,938 в.c.

Valves of pelecypods (Ostrea sp. and Chama sp.) from base of tertiary anticline (old shoreline) on W margin of Lake Mc. Leod, W. Australia (23 $32^{\prime} \mathrm{S}$ Lat, $113^{\circ} 52^{\prime} \mathrm{E}$ Long). Sample locality is ca. 15 to $20 \mathrm{ft}$ above mean sea level. Coll. 1966; subm. by G. R. Davis. 
II. ARCHAEOLOGIC SAMPLES

ORINS-75. Kum River, Korea

$5,596 \pm 600$

3,646 B.C.

Organic silt from Kum R. prehistoric excavation site $36^{\circ} 27^{\prime} \mathrm{N}$ Lat, $127^{\circ} 9^{\prime}$ E Long), Korea. Sample obtained $600 \mathrm{~cm}$ below present vegetation level. Coll. 1966; subm. by P. K. Sohn, Yonsei Univ., Seoul, Korea. Comment: sample treated with dil. alkali and acid and dry-combusted.

\section{ORINS-83. Grassy Cove Cave, Tennessee}

$3,404 \pm 68$ 1,454 B.C.

Fecal pellets containing visible grass and other undigested vegetation from karst cavernous formation ( $36^{\circ} 30^{\prime} \mathrm{N}$ Lat, $85^{\circ} 30^{\prime} \mathrm{W}$ Long), Crossville, Tennessee. Sample from attic formation of Grassy Cove Cave in dry uncovered condition. Coll. 1967; subm. by Fred Fischer, ORAU Research Participant, Oak Ridge, Tennessee. Comment: sample treated with dil. alkali and acid and dry-combusted.

\section{REFERENCFS}

Barker, H., 1953, Radiocarbon dating; large scale preparation of acetylene from organic material: Nature, v. 172, p. 631-632.

Godwin, H., 1962, Half-life of radiocarbon: Nature, v. 195, p. 984.

Noakes, J. E., Kim, S. M., Stipp, J. J., and Akers, L. K., 1965, Chemical and counting advances in liquid scintillation radiocarbon dating: Sixth International Conference Radiocarbon and Tritium Dating, Proc., Conf. -650652, p. 68-92.

Noakes, J. E., Kim, S. M., and Akers, L. K., 1967, Oak Ridge Institute of Nuclear Studies Radiocarbon Dates I: Radiocarbon, v. 9, p. 309-315. 